\title{
DESIGN GRÁFICO E RESPONSABILIDADE SOCIAL: A TEORIA DE VICTOR PAPANEK E A PRÁTICA DO DESIGN CONTEMPORÂNEO NO BRASIL
}

\author{
Michele Queiroz Farran \\ Universidade Positivo \\ telefarran@hotmail.com \\ Ana Paula França \\ Universidade Positivo \\ anapaulafranca@up.com.br
}

Resumo: Os questionamentos a cerca da função social do design gráfico se intensificam num mundo cada vez mais globalizado. Sendo um parceiro importante do consumismo e propagação do desejo, o design se torna cada vez mais requisitado. Foi durante a década de 70 que a sociedade começou a demonstrar sintomas de um colapso produtivo e ambiental, e nesta época também que o designer e estudioso Victor Papanek se destaca com publicações propõe mudanças na prática do design e debate o papel social da profissão. A revisão bibliográfica desta pesquisa se justifica na medida que a análise de diferentes movimentos artísticos e sociedades de design gráfico possuem posições diversas no que se diz respeito à responsabilidade social. $O$ próprio nascimento do design, durante o auge da Revolução Industrial em meados do século XIX, com o movimento Arts $E$ Crafts, fomentava, por meio de seus integrantes e discursos, que o design era peça fundamental no reformismo social em face das consequências negativas da industrialização (CARDOSO, 2008). Tal postura voltou a ser clamada na década de 1970 do século XX, quando a sociedade de consumo demostrou sintomas de colapso irrevogáveis. A crise do petróleo desencadeou uma consciência em torno da sustentabilidade, sendo a primeira concretização econômica do limite dos recursos naturais (KAZAZIAN, 2005). O pensamento teórico de Victor Papanek destaca-se nesse contexto, tendo como marco a publicação do livro Design para um mundo real, em 1971, e do texto síntese de todos seus preceitos, Edugrafologia, que foi publicado, originalmente, em 1975. Em suas obras, Papanek defende um novo sentido para o design em face de um mundo assolado pela miséria, violência e degradação (CARDOSO, 2012). Tal proposta obteve um espaço especial no Brasil. Segundo o estudioso Dijon de Moraes (2006), o país configurava-se, na década de 1970, como terreno fértil para polêmicas relacionadas à exclusão da indústria convencional no processo de desenvolvimento tecnológico. A tecnologia alternativa, proposta por Papanek, tornou-se instrumento de protesto contra o modelo colonialista industrial predominante. Este projeto articula os preceitos teóricos da obra Edugrafologia (1975) para se obter uma melhor compreensão do design brasileiro contemporâneo. A partir desta premissa, 
foi desenvolvido material de referência (tabela comparativa e quadro de conceitos) visando identificar o diálogo entre os conceitos e apontamentos presentes no texto Edugrafologia e projetos de design identificados no catálogo da Bienal Brasileira de Design do ano de 2015. Foi realizada uma interpretação do diálogo entre os projetos com o quadro de conceitos para assim chegar numa conclusão indutiva sobre o papel da responsabilidade social na produção do design brasileiro contemporâneo. Os projetos selecionados agiram como representantes do design brasileiro contemporâneo geral por se tratarem de projetos de destaque no âmbito nacional. E, assim, a representatividade do design socialmente responsável pode ser melhor analisada no cenário brasileiro.

Palavras-chave: Design, História do Design, Victor Papanek, Bienal Brasileira do Design 